\title{
THE INFLUENCE OF CORPORATE DISCLOSURE LEVEL ON COST OF EQUITY CAPITAL: EVIDENCE FROM INDONESIA
}

\author{
Angela Tamara ${ }^{1}$ \\ BINUS University International \\ Yanthi Hutagaol ${ }^{2}$ \\ BINUS University International
}

\begin{abstract}
This research investigates the level of corporate disclosure in Indonesia and how corporate disclosure may influence company's cost of equity capital. Moreover, this research is also wanted to investigate the profile of corporate disclosure in Indonesia.

The samples used in this research are companies that are listed in LQ45 from 2006 to 2010 . The corporate disclosure information is derived from the annual report. Moreover, related information required are also extracted from annual report, such as leverage, total asset and auditor quality. For data analysis, this research will employ a multiple regression to determine the association among variables.

The result shows the disclosure level in Indonesia is actually affected cost of equity capital even though the level of significant is considered as low.

As the conclusion, although most of companies does not disclosed information as the expected number of regulation, Indonesia capital market still can be considered as semi strong since the information that are available for public are actually affecting investors decision on investment.
\end{abstract}

Keywords: corporate disclosure, cost of equity capital.

\footnotetext{
${ }^{1}$ Graduated from School of Accounting (ngelangelatamara@yahoo.com)

${ }^{2}$ Faculty of Business, School of Accounting and Finance (yhutagaol@binus.edu)
} 


\section{INTRODUCTION}

\section{Background}

Corporate disclosure has an important role in creating an efficient capital market. (Healy and Palepu, 2000). In order to achieve this purpose, government regulated some acts regarding corporate disclosure in the annual report. A corporate disclosure in Indonesian capital market is regulated by Badan Pengawas Pasar Modal and Lembaga Keuangan (BAPEPAM-LK). According to Keputusan Ketua Pengawas Pasar Modal dan Lembaga Keuangan No: KEP134/BL/2006 rules No: X.K.6, there are 2 reasons that being considered by BAPEPAM-LK why it is important to regulate company's annual report, which are: (1) company's annual report is an important source for both of investor and other people in making investment decision, (2) to improve the quality information disclosure in annual report, which also to improve the previous Peraturan Bapepam Nomor VIII.G.2, Lampiran Keputusan Bapepam Nomor: Kep-38/PM/1996. By improving information quality of a company, it is expected that investor could make a decision based on reliable source of information as their consideration.

The level of corporate disclosure is varying from one to another company. A company may reveal a high disclosure level in order to make an investor interested in them. By having a deeper knowledge and understanding, the demand of certain company's share will increase, thus it also enhance stock liquidity. (Botosan, 1997). Moreover, having a great understanding will also lower investor's risk over certain stock; therefore it will lower the share return. When the company's share return is relatively low, the company's cost of equity will also become lower since the company does not have to pay a large amount of money to its investor.

\section{THEORETICAL FRAMEWORK}

\section{Corporate Disclosure}

Considering to the needs of information disclosure, government regulated several law regarding corporate disclosure. As being discuss in the introduction section, corporate disclosure in Indonesia is also regulated by Keputusan Ketua Pengawas Pasar Modal dan Lembaga 
Keuangan No: KEP-134/BL/2006 rules No: X.K.6. Actually this act described about the structure and contain of annual report. Every company listed in IDX has to follow this regulation in preparing their annual report. In addition to that, a company may disclose any other information excluding the one which has been regulated, thus later it is called as voluntary disclosure. Disclosing significant and relevant information regarding company performance is important for company's stakeholders. In addition to that, Healy, Hutton and Palepu (1999) argued there might be two potential benefits for company who disclose an additional information to public, which are, the first one is it could help them in dealing with a wrong firm valuation, whereas the second benefit will be it may enhance the potential investor interest in the company, therefore it may increase the company's share liquidity.

\section{Information Asymmetry Problem}

Under information perspective in accounting policy, managers have to provide related information for its investors in order to facilitate them in making investment decision (Godfrey, Hudson, Holmes \& Tarca, 2006). In the book, Godfrey et al (2006) point out that "managers undertake this role because they have a comparative advantage in the production and dissemination of information" (p.315). When one party in the market (seller for instance) having a better understanding about certain asset sold in the market than other party (buyer or investor), information asymmetry does exist (Scott, 2003).

\section{Cost of Equity}

The firm cost of capital will reflect to the cost spent by the firm from its sources of financing. (Keown, Martin, Petty \& Scott, 2005). Meanwhile, cost of equity capital identifies investors' required rate of return on the stock investment. (Gitman, 2009). Investors' required return can be calculated by computing the difference in the market value of shares, which might also known as capital gain. There are two models that usually be used in calculating firm's cost of equity, which are Gordon Growth Model and Capital Asset Pricing Model (CAPM). (Gitman, 2009).

\section{Other Variables Affecting Cost of Equity Capital}

\section{- Leverage}

Leverage of a firm can be defined as the result if using fixed-cost asset in generating return. (Gitman, 2009). Gitman (2009) also 
pointed that it is usual that an increase in leverage will result an increase in return and risk, vice versa.

\section{- Auditor Quality}

According to Fernando et al (2010), the auditor quality influence the firm's cost of equity capital. In their research, Fernando et al (2010) argue that Big 4 auditors will be able to provide a better audit quality than non-Big 4 audit firm. Moreover, Fernando et al (as cited in Casterella, 2004) pointed that "auditor specialization as a differentiation strategy whose purpose is to provide auditors with a sustainable competitive advantage over non-specialist"; therefore, according to this theory, a firm which being audited by a specialist auditor has a tendency to provide a better assurance rather than the non-specialist.

\section{- Firm Size}

According to Bozec and Bozec (2010), the size of a firm influences the firm's cost of capital. The firm with a high total asset has a tendency to have more operating activities; hence it will lower their need in raising external fund for the business operation. (Bozec and Bozec, 2010).

\section{Efficient Market Hypothesis}

The announcement of accounting information to public has influenced the behavior of capital market, especially the share prices. (Godfrey, 2006). The underlying theory that supports the relationship between accounting information and market reaction refer to "Efficient Market Hypothesis".

Considering to the previous research engaged by Fama, he differentiate the types of information into three types, which are weak form, semi-strong form and strong form of market. The equity market in capital market research is expected to be semi-strong form which all related information in public is influencing share prices. (Deegan, 2010).

\section{Hypothesis Development}

As being discuss above, corporate disclosure is important in delivering company's information for its stakeholder, especially investors. Having a reliable and transparent corporate disclosure will lead to higher trust of investors, thus it will increase number of share liquidity in the future. As discussed above, corporate disclosure had been proved in affecting company's cost of equity capital (e.g., 
Botosan, 1997; Cheng, Collins \& Huang, 2006; Diamond \& Verrecchia, 1991). By having a deeper knowledge regarding company's performance, it would reduce company's cost of equity capital through a lower share return to be paid to investors. Taking the following literatures into account, the first conceptual hypothesis of this research as follows:

H1: There is a negative relationship between corporate disclosure and company's cost of equity capital.

$\mathrm{H} 2$ : There is a positive relationship between firm leverage and company's cost of equity capital.

H3: There is a negative relationship between auditor quality and company's cost of equity capital.

H4: There is a negative relationship between firm size and company's cost of equity capital.

\section{RESEARCH METHODOLOGY}

\section{Research Aim}

This research aims to determine the influences of corporate disclosure level on company's cost of equity capital. In order to achieve the purpose of this research, the author has formulated a research question as follow:

1. How company's disclosure level influence company's cost of equity capital?

2. How the finding of this research compared to the previous research engaged regarding disclosure level?

\section{Research Design}

\section{Measurements and Measures}

There will be several proxies used as the measurement in determining factors that influence company's cost of equity capital. This section will cover the operational terms of each proxy, as follows:

\section{- Cost of Equity Capital}

This research will utilize the industry adjusted earnings-price ratio as the measurement for cost of equity capital. According to Francis, LaFond, Olsson, and Schipper (2005), the price multiple related to earnings can be considered as short-hand valuation. It also stated that earnings-price ratio is used to consider the effects of low earning value to share prices. (Francis et al, 2005). ADJ_EP is calculated as 
the difference between company EP and median of industry EP in certain year, hence the formula is as follows:

Where:

\section{ADJ_EPi $=\mathbf{E P i}-$ IndMed EP}

ADJ_EPi is industry adjusted earnings-price ratio of firm i; EPi is earnings-price ratio of firm $i$ and IndMed EP is median of industry earnings-price ratio.

In addition to that, Francis et al (2005) also argued that a higher earnings-price ratio indicates lower cost of equity capital, since shareholders agree to pay a higher share price for the earnings.

\section{- Disclosure Level}

As for the disclosure measurements, this research will refer to Keputusan Ketua Pengawas Pasar Modal dan Lembaga Keuangan No: KEP-134/BL/2006 rules No: X.K.6 as the guideline in classifying the type of disclosure, whether specific disclosure is categorized as mandatory disclosure or voluntary disclosure. The proxy to measure disclosure information in this research is the number of disclosure in annual report. Then the sum of information disclosure, both of mandatory and voluntary will be indicated as corporate disclosure level.

\section{- Leverage}

Company's leverage is characterized by Debt Ratio as its proxy. The operational term is as follows:

$$
D R=\frac{T L}{T A} \times 100 \%
$$

Where: DR is debt ratio of firm for current year; TL is total liabilities of firm at end of year and TA is total assets of firm at end of year.

- Auditor Quality

As adapted from Fernando, Abdel-Meguid \& Elder (2010), the auditor size and auditor industry specialization will be examined in determining company's cost of capital. For the audit size, there will be two classifications used in this research, which are Big4 and non-Big4 audit companies. The auditor size will be treated as dummy variable in this research, where Big4 Company is assigned to value of 1, while a non-Big4 audit firm is assign to value of 0 . Moreover, for the auditor industry specialization, the author will divide the companies into 9 industry sectors exist in Indonesia. The author will also treat the 
industry specialization as a dummy variable in this research. Once a company shows its industry specialization, it will be valued as 1 , else it will be valued as 0 in other industries. The classification will be done in Microsoft Excel spreadsheet.

\section{- Firm Size}

In determining the size of company, the author will use the company's total asset as the proxy. The company's total asset is simply retrieved from the balance sheet.

\section{Sampling Design}

In developing this research, the author uses a non probability sampling. In this research, the companies listed in LQ 45 during period of 2006 to 2010 will be used as the sample. In addition to that, this research applies a purposive sampling method since the author selects the group of companies listed in LQ 45 purposely as the sample.

\section{Research Models}

The dependent variable used in this research is cost of equity capital since the research is aiming to find out the effect on cost of equity capital related to the independent variables, which is the corporate disclosure level. Moreover, there are 3 control variables that are going to assess in this research, which are leverage, auditor quality and size. The relation among control variables, independent variables, and dependent variables can be expressed in mathematical equation as follows:

ADJ_EP $P_{i}=\beta_{0}+\beta_{1}$ DISC $_{i}+\beta_{2}$ LEV $_{i}+\beta_{3}$AUD $_{i}+\beta_{4}$ SIZE $_{i}+\varepsilon \ldots$ (1)

Where:

ADJ_EP $\mathrm{i}_{\mathrm{i}}$ is industry adjusted earnings-price ratio of firm $\mathrm{I} ; \beta_{0}$ is intercept; $\beta_{1}, \beta_{2}, \beta_{3}, \beta_{4}$ are regression coefficients; DISC $_{i}$ is number of firm's disclosure level; $\mathrm{LEV}_{\mathrm{i}}$ is leverage level of firm I; $\mathrm{AUD}_{\mathrm{i}}$ is auditor quality level of firm $i$ and SIZE $_{i}$ is size of firm $i$.

For further analysis, this research will also determine each disclosure type impacts on cost of equity capital by differentiate the mandatory and voluntary disclosure level. 
Therefore, there relation among variables can be expressed in mathematical equation as follows:

$$
\begin{gathered}
\text { ADJ_EP }_{i}=\beta_{0}+\beta_{1} \operatorname{DISCM}_{i}+\beta_{2} \operatorname{DISCV}_{i}+\beta_{3} \text { LEV }_{i}+\beta 4 \text { AUD }_{i}+\beta_{5} \\
\operatorname{SIZE}_{i}+\varepsilon \ldots(2)
\end{gathered}
$$

Where:

DISCM $_{i}$ is number of firm mandatory disclosure level and DISCV $V_{i}$ is number of firm voluntary disclosure level

\section{FINDINGS AND DISCUSSION}

\section{Final Sample Selection}

As being described at Chapter 3, this research will utilize LQ 45 firms from year 2006 to 2010 as the sample. The sample selection will include all listed firms in LQ 45 during this specific period of time. Any new listing company in the subsequent year will be taking into account as the addition of sample. Therefore, within 5 years of observation period, there are 43 firms added to the initial sample firms, hence there are 88 firms in total. In this research, the author will use the data of these 88 firms starting from 2006 to 2010, although certain company is not listed in LQ 45 since the beginning of observation period, regardless some companies have not done their IPO yet. Moreover, even if there is a company being delisted from LQ 45 index, it will be still included in the subsequent year observations. However, not all the sample above is included in this research due to the unavailability of the data, particularly annual report and share price data. Hence, the final firm year observation is as follows:

Table 1. Final Firms Observation (in Firm Years)

\begin{tabular}{|l|r|}
\hline Expected number of observation & 440 \\
\hline Reduction due to IPO & 23 \\
\hline Reduction due to delisting & 5 \\
\hline Reduction due to merger & 5 \\
\hline Reduction due to data unavailability (Annual Report) & 50 \\
\hline Reduction due to data unavailability (Share Prices) & 9 \\
\hline Total observations & 348 \\
\hline
\end{tabular}




\section{Descriptive Statistics}

In this section, the measurements of data observations will be examined and discussed. The data presented below are the dependent variable and independent variables employed in this research, which are ADJ-EP (industry-adjusted earnings to price ratio), DISC (number of firm's disclosure level), DISCM (number of firm's mandatory disclosure level), DISCV (number of firm's voluntary disclosure level), LEV (leverage level), AUD (auditor quality level), SIZE (natural logarithm of total asset). The aim of descriptive statistics is to provide general facts regarding the data. Therefore, the descriptive statistics over the observation is presented as follow:

Table 2. Descriptive Statistics

\begin{tabular}{|c|ccccccc|}
\hline & ADJ_EP & DISC & DISCM & DISCV & AUD & LEV & SIZE \\
\hline Mean & -0.03223 & 22.97126 & 20.68103 & 2.29023 & 1.158046 & 0.551292 & 30.00928 \\
Median & 0 & 23 & 21 & 2 & 1 & 0.54 & 29.78398 \\
Maximum & 1.653488 & 33 & 25 & 8 & 2 & 1.468362 & 33.73977 \\
Minimum & -4.69239 & 11 & 11 & 0 & 0 & 0.108645 & 21.44883 \\
Std. Dev. & 0.381291 & 3.816283 & 2.943069 & 1.495128 & 0.818214 & 0.236576 & 1.552946 \\
\hline
\end{tabular}

From the descriptive statistics table above, it shows that the average ADJ_EP of 348 observations from 2006 to 2010, indicated by mean, is $-\overline{0} .03212$. The negative value of ADJ_EP indicates that the company relatively has a small earning-price ratio compared to other companies within the same industry. Moreover, the negative value of ADJ_EP means a high cost of equity capital.

Furthermore, the disclosure level (DISC) has a mean value of 22.97126437. It means that from 348 observations, the average of disclosure level is 22.97126437, which in this case we can assume it as 23 items being disclosed. The average of DISC indicates most of the company has a tendency to disclose less than the number of regulated disclosure. BAPEPAM has regulated 25 components of corporate disclosure; meanwhile the average is only 23 .

\section{Regression}

In this section, the regression result of the two models employed in this research is being discussed and analyzed. The first model is as follows: 
Table 3. Model 1

\begin{tabular}{|c|c|c|c|}
\multicolumn{1}{|c|}{ ADJ_EP $\mathbf{E}_{\mathbf{i}}=\boldsymbol{\beta}_{\mathbf{0}}+\boldsymbol{\beta}_{\mathbf{1}} \mathbf{D I S C}_{\mathbf{i}}+\boldsymbol{\beta}_{\mathbf{2}} \mathbf{L E V}_{\mathbf{i}}+\boldsymbol{\beta}_{\mathbf{3}} \mathbf{A U D}_{\mathbf{i}}+\boldsymbol{\beta}_{\mathbf{4}} \mathbf{S I Z E}_{\mathbf{i}}+\boldsymbol{\varepsilon}$} \\
\hline Variable & Coefficients & t-statistics & p-value \\
\hline Cons & -0.09 & -0.223 & 0.412 \\
DISC & 0.005 & 0.925 & 0.178 \\
LEV & -0.329 & -3.561 & 0.000 \\
AUD & 0.49 & 1.994 & 0.0235 \\
SIZE & 0.002 & 0.144 & 0.4425 \\
\hline F-statistics & 4.909 & \multicolumn{3}{l}{} \\
\hline Adjusted R Square & 0.043 & 0.001 \\
\hline
\end{tabular}

Table 3 above shows that the adjusted R Square of the first model is 0.043 or it can be considered as $4.3 \%$. This means the first model explains $4.3 \%$ of variance in the industry-adjusted earnings-price ratio (ADJ_EP). Moreover, this model can be considered statistically significance since the p-value of the F-test is lower than 0.05 .

Additionally, each variable significance contribution is also explained in table 5, which in this case it is indicated by p-value. The table shows that both of LEV and AUD provide a significance contribution in explaining ADJ_EP since the p-value is significant at level 0.000 and 0.0235 respectively. However, DISC and SIZE seem to provide an insignificant contribution in explaining ADJ_EP since both of its $\mathrm{p}$-value is greater than 0.005 .

Since this research is having 2 models for the analyzing, the following table will describe the regression analysis of the second model employed in this research.

Table 4. Model 2

ADJ_EP E $_{i}=\beta_{0}+\beta_{1}$ DISCM $_{i}+\beta_{2}$ DISCV $_{i}+\beta_{3}$ LEV $_{i}+\beta 4$ AUD $_{i}+$ $\beta_{5} \operatorname{SIZE}_{\mathbf{i}}+\varepsilon$

\begin{tabular}{|c|c|c|c|}
\hline Variable & Coefficients & t-statistics & p-value \\
\hline Cons & -0.193 & -0.466 & 0.321 \\
DISCM & 0.011 & 1.444 & 0.075 \\
DISCV & -0.01 & -0.697 & 0.243 \\
LEV & -0.345 & -3.692 & 0.000 \\
AUD & 0.049 & 1.999 & 0.023 \\
SIZE & 0.003 & 0.195 & 0.423 \\
\hline F-statistics & 4.181 & & 0.001 \\
\hline Adjusted R Square & 0.044 & \\
\hline
\end{tabular}


Table 4 above shows 0.044 adjusted R- Square of the independent variables. This means the second model only explains $4.4 \%$ of variance in the ADJ_EP. Furthermore, this model can be also considered statistically significance with p-value of 0.001 .

\section{Hypothesis Testing}

Based on the measurement of cost of equity capital explained in chapter 3, the conceptual hypotheses are changing into working. Meanwhile, the summary of statistical test of coefficient regression is as follows:

Table 5. Statistical Test Summary

\begin{tabular}{|c|c|c|c|}
\hline Variable & Expected Sign & t-statistics & $\mathrm{p}$-value \\
\hline Cons & N/A & -0.223 & 0.412 \\
DISC & + & 0.925 & 0.178 \\
LEV & - & -3.561 & 0.000 \\
AUD & + & 1.994 & 0.0235 \\
SIZE & + & 0.144 & 0.4425 \\
DISCM & + & 1.444 & 0.075 \\
DISCV & + & -0.697 & 0.243 \\
\hline
\end{tabular}

Where the first model is as follows:

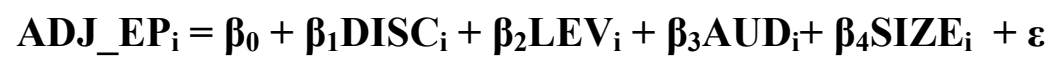

The discussion of working hypothesis is as follows:

H1: There is a positive relationship between corporate disclosure and company's industry-adjusted earnings-price ratio.

Considering to prior conceptual hypothesis, which assume that there is a negative relationship between corporate disclosure and company's cost of equity capital, this conceptual hypothesis is also accepted since the underlying theory consider that high ADJ_EP equals to low cost of equity capital. This first hypothesis is actually supported by several previous researches, such as Botosan, 1997; Cheng, Collins \& Huang, 2006 and Diamond \&Verrecchia, 1991. Botosan (1997) argue that deeper knowledge of corporate condition may influence investor decision in making investment, thus it improve shares liquidity then lower company's cost of equity capital. 
$\mathrm{H} 2$ : There is a negative relationship between firm leverage and company's industry-adjusted earnings-price ratio.

Relates to the conceptual hypothesis, which assumes there is a positive relationship between firm leverage and company's cost of equity capital, this conceptual hypothesis is accepted. The lower is company's leverage, it will increase company's ADJ_EP thus it lead to a lower cost of equity capital. The result is actually consistent with the previous research engage by Cheng et al, 2006. Cheng et al (2006) argues that a high leverage is associated with a high credit risk. When investors feel that the company risk is relatively high, they will require a high share return, hence it will increase company's cost of equity capital.

H3: There is a positive relationship between audit quality and company's industry-adjusted earnings-price ratio.

Relates to the conceptual hypothesis that assumes there is a negative relationship between auditor quality and company's cost of equity capital, this conceptual hypothesis is also accepted since auditor quality is decreasing cost of equity capital through a high value of AD_EP. The result discussed above is actually similar with previous research conducted by Fernando, Abdel-Meguid, Elder (2010). Fernando et al (2010) pointed that a good quality of auditor has a tendency to give better audit assurance. By having reliable information, it could minimize investor risk; therefore it will decrease company's cost of equity capital by lowering the share return.

H4: There is a positive relationship between firm size and company's industry-adjusted earnings-price ratio.

Consider to the conceptual hypothesis that assumes that there is a negative relationship between company size and company's cost of equity capital; this conceptual hypothesis is also accepted. The finding discussed above is actually consistent with Cheng et al (2006). The paper found that the larger company size has a low cost of equity capital since it is likely the company with high total asset is having advantage in paying investor return.

Whereas the second model is:

$$
\underset{\text { ADJ_EP }_{i}=\beta_{0}+\beta_{1} \text { DISCM }_{i}+\beta_{2} \text { DISCV }_{i}+\beta_{3} \text { LEV }_{i}+\beta 4 A_{\text {UDD }}+}{\beta_{5} \text { SIZE }_{i}+\varepsilon}
$$


H5: There is a positive relationship between corporate mandatory disclosure and company's industry-adjusted earnings-price ratio.

Relates to the conceptual hypothesis, which assumes that there is a negative relationship between corporate mandatory disclosure and company's cost of equity capital, this conceptual hypothesis is accepted as the higher corporate mandatory disclosure level is lowering cost of equity capital through a high value of ADJ_EP. Unfortunately, there is insufficient evidence to prove the specific relationship between DISCM and cost of equity capital since most of the journals are assessing either voluntary disclosure or both of voluntary and mandatory disclosure.

H6: There is a positive relationship between corporate voluntary disclosure and company's industry-adjusted earnings-price ratio. Relates to the conceptual hypothesis, which assumes that there is a negative relationship between corporate voluntary disclosure and company's cost of equity capital, this conceptual hypothesis is rejected as the higher number of voluntary disclosure is improving cost of equity capital through low value of ADJ_EP. Unfortunately the result above does not seem to agree with Botosan (1997). In her paper, Botosan (1997) found that voluntary disclosure can lower company's cost of equity since this additional disclosure is giving a deeper knowledge hence it lower the investment risk. However, there is insufficient research that supports this finding. Banghoj and Plenborg (2008) argued that the irrelevance information in voluntary disclosure is actually increasing the risk, hence the cost of equity capital become higher.

\section{CONCLUSION AND RECOMMENDATION}

\section{Conclusion}

The relation between corporate disclosure and cost of equity has been debated whether these two are actually related. The high level of corporate disclosure is believed to improve investors' knowledge. (Botosan, 1997). When investors have a better understanding of the company and consider the performance as good, they will started to invest therefore it will enhance the share liquidity. (Gruning, 2011). However, the consistency of corporate disclosure is also important to 
be considered, whether the company's disclosure is getting better year-by-year or getting worst.

Considering to the findings on chapter 4 , the corporate disclosure in Indonesia can be considered as vulnerable since many of the company disclose the information does not consider to the regulation. The descriptive statistics discussion in chapter 4 shows that the number of corporate disclosure is varies from one company to others. For instance, PT Aneka Tambang Tbk disclosed 27 items in its 2006 annual report, whereas, PT Unilever Tbk only disclosed 15 items in its 2006 annual report. Therefore, it can be assumed that the corporate disclosure in Indonesia is still unsteady even though there is a strict law regulated.

Moreover, based on the correlation discussion in chapter 4, there is a negative relationship between corporate disclosure and cost of equity capital. The result shows there is insignificant relationship between these two variables. As the conclusion, the corporate disclosure in Indonesia can be considered factors that may influence company's cost of equity capital even though the corporate disclosure has a relatively low influence. This research also proved that the company information is actually affected investor expectation in the market, hence Indonesia capital market can be considered as semi-strong in efficient market hypothesis.

\section{REFERENCES}

Botosan, C.A. (1997). Disclosure Level and the Cost of Equity Capital. The Accounting Review, 72(3), 323-349. Retrieved from EBSCO Host database.

Bozec, Y., Bozec, R. (2010). Overall Governance and Cost of Capital: Evidence From Canada Using Panel Data. Journal of Global Business Management, 6, 1-11. Retrieved from ProQuest Education Journals database.

Cheng, C.S.A, Collins, D., Huang, H.H. (2006). Shareholder rights, financial disclosure and the cost of equity capital. Rev Quant Finan Acc (2006), 27:175-204. doi: 10.1007/s11156-0068795-2. Retrieved from EBSCO Host database. 
Diamond, D.W, Verrecchia, R.E. (1991). Disclosure, Liquidity, and the Cost of Capital. The journal of finance Vol XLVI, No.4. Retrieved from EBSCO Host database.

Fernando, G.D, Abdel-Meguid, A.M, Elder, R.J. (2010). Audit quality attributes, client size and cost of equity capital. Review of Accounting and Finance Vol. 9 No. 4, 2010, pp. 363-381. doi: 10.1108/14757701011094571. Retrieved from ProQuest Education Journals database.

Francis, J., LaFond, R., Olsson, P., Schipper, K. (2005). The market pricing of accruals quality. Journal of Accounting and Economics 39, 295 - 327. Retrieved from EBSCO Host database.

Gietzmann, M., Ireland, J. (2005). Cost of Capital, Strategic Disclosure and Accounting Choice. Journal of Business Finance \& Accounting, 32(3). Retrieved from EBSCO Host database.

Gitman, L.J. (2009). Principles of Managerial Finance $\left(12^{\text {th }}\right.$ ed). United States: Pearson Education.

Godfrey, J., Hodgson, A., Holmes, S., \& Tarca, A. (2006). Accounting Theory $\left(6^{\text {th }}\right.$ ed). Queensland, Australia: John Wiley \& Sons Australia, Ltd.

Gruning, M. (2011). Capital Market Implications of Corporate Disclosure: German Evidence. Business Research Vol 4, Issue 1, 48-72. Retrieved from EBSCO Host database.

Healy, P.M, Hutton, A.P, Palepu, K.G. (1999). Stock Performance and Intermediation Changes Surrounding Sustained Increases in Disclosure. Contemporary Accounting Research Vol. 16, No 3, 485-520. Retrived from ProQuest Education Journal database.

Healy, P.M, Palepu, K.G. (2000). Information asymmetry, corporate disclosure, and the capital markets: A review of the empirical disclosure literature. Journal of Accounting and Economics 31, (2001), 405-440. Retrieved from ProQuest Education Journals database. 
Keown, A.J, Martin, J.D, Petty, J.W, Scott, D.F. (2005). Financial Management: Principles and Applications $\left(10^{\text {th }}\right.$ ed). New Jersey, United States: Pearson Prentice Hall.

Khurana, I.K., Raman, K.K. (2004). Litigation Risk and the Financial Reporting Credibility of Big 4 versus Non-Big 4 Audits: Evidence from Anglo-American Countries. The Accounting Review Vol. 79 No.2, 2004, 473-495. Retrieved from ProQuest Education Journals database.

Koller, T., Goedhart, M., Wessels, D. (2005). Valuation: Measuring and Managing the Value of Companies. New Jersey, United States: John Wiley \& Sons, Inc.

Sekaran, U., Bougie, R. (2009). Research Method for Business: A Skill Building Approach ( $5^{\text {th }}$ ed). United Kingdom: John Wiley \& Sons, Ltd.

Scott, W.R. (2003). Financial Accounting Theory ( $3^{\text {rd }}$ ed). Toronto, Ontario, Canada: Prentice Hall.

Zhang, L. Ding, S. (2006). The effect of increased disclosure on cost of capital: Evidence from China. Rev Quant Finan Acc (2006), 27:383-401. doi: 10.1007/s11156-006-00440-1. Retrieved from EBSCO Host database. 